\title{
The Relationship between Firms' Environmental Performance and Financial Performance: The Case of Turkey
}

\author{
Asst. Prof. Dr. Füsun Küçükbay (Celal Bayar University, Turkey) \\ Ph.D. Candidate Tuğba Arpazlı Fazlılar (Celal Bayar University, Turkey)
}

\begin{abstract}
In recent years, the number of firms that give importance to environmental problems such as consumption of natural resources, decline in water resources and global warming are increasing. However, the classical view of literature argues that firms' environmental protection operations decrease the financial performance of them. For that reason, in this study, it is aimed to analyze the relationship between financial performance and environmental performance of the firms. The sample of the study consists of firms listed on Borsa Istanbul 100 index and has a climate change score declared in CDP Turkey Climate Change Report 2015. Climate change score is used for measuring environmental performance. Accounting (Return on Asset) and marketing measures (Market Value/Book Value) are used for measuring financial performance. The relationship between the environmental performance and financial performance of the firms compared with the help of correlation analysis. Findings reveal that there is a positive relation between financial performance and environmental performance. The correlation between market performance and environmental performance is weaker than the correlation between accounting performance and environmental performance. Moreover, multidimensional scaling technique is utilized to cluster the firms in terms of their financial and environmental performance. A map is formed with the help of multidimensional scaling that shows the relative positioning of the sampled firms due to their environmental performance and financial performance.
\end{abstract}

\section{Introduction}

"Sustainability concept" has been discussed in the literature for years. This concept generally described as meeting the demands of people with concerning the responsibilities towards society and the environment and concerning future generations (Bekmezci, 2014). On the other hand, the concept of environmental pollution and environmental issues are also discussed over years in academic studies, but it is responsed in real life quite lately and inadequately.

The firms' product varieties are all shaped by customer demand. As a result of this; today the ecological footprint are $\% 50$ more than the world's biological capacity, this causes the environmental problems and give harm to sustainability. Each year 2,5 ppm (parts per million to atmosphere) carbondioxit are added (twice more than that of 30 years ago) which pollutes the water resources and air rapidly. These developments cause everyone to think about the environmental issues. Consequently, both legal authorities and the firms' authorities start to discuss the role of firms in environmental issues.

In the production process of the firms, harmful wastes occur that threatens the environment seriously. So that, the firms should give importance to environmental issues and should transform their structures from the "brown economy", that have low sensitivity and profit-centric, to the model of 'green economy', that give importance to environmental sustainability (Pointing, 2012; Sukhdev, 2013). According to Shukdev (2013), four fundamental changes has to be made by firms in order to achieve the green economy model and these four reforms ensure both profitability and environmental sustainability:

- First one is reorganizing the taxes and subsidizes. The "bads" such as using fossil fuel have to be taxed more whereas the "goods" such as wages and profit have to be taxed less.

- Second, the rules and limits have to be defined to govern the financial leverage, especially if the borrower is considered "too big to fail".

- $\quad$ Third, advertising norms and standards have to be developed that are more responsible and accountable. For example disclosing the life span of the product or the disclosing the countries of the product.

- $\quad$ The last one is measuring, auditing and reporting the all important externalities in the annual financial statements of the firms. In this way the firms are more transparent and accountable.

Based on this views, many studies in the literature investigate the relationship between environmental performance and financial performance of the firms. According to the literature review, findings in these studies demonstrate that positive correlation is predominant between link of them. For example, Moneva and Ortas (2009) analyzed the environmental and financial performance of a sample of 230 European firms with a partial least squares model (PLS). According to this study the results support the idea that enterprises which obtained higher rates of environmental performance show better financial performance levels in the future. Sahay and Sing (2005) examine the relationship between the environmental performance and the financial performance for different sectors like a pulp and paper, automobile and caustic-chlorine with net sales, PBDIT, net worth and total assets datas. The analysis shows that all the financial parameters have negative correlation for a pulp and paper sector. 
Contrarily, in the automobile sector and the caustic-choline sector, there is a positive correlation among of them. Sahay and Sing (2005) argue that different correlation results for different sectors are because each sector has different level of technology. Jimenez et al. (2013) investigate that why and when the positive correlation occurs between environmental protection and financial performance. However, in this study differences between environmental protections, environmental management practices, environmental proactivity and environmental performance for the firms are emphasized. In the study, regression analysis is used and the sample of the study consists of 186 Welsh firms. According to the results, financial performance has a positive and significant correlation with environmental proactivity and environmental performance, while it has no significant relation with environmental management. Qi et al. (2014) investigate the relationship between environmental and financial performance of Chinese firms. They gather data on all Chinese industrial sectors such as mining, manufacturing and electricity. These industries are the primary source of environmental pollution in China. Qi et al. (2014) use a dynamic panel model in their study. Findings of the paper show that the firm-level conclusion on the environmental performance and financial performance link is consistent with the industry-level analysis. In addition to this, their research supports the hypothesis that resource slack plays a moderating role on environmental performance and financial performance. They argue that these findings suggest that investing in environmental improvements improve firms' financial performance. Muhammad et al. (2015) examine the relationship between environmental performance and financial performance of publicly held firms in Australia for the pre-crisis period (2001-2007) and the post-crisis period (2008-2010). The study consist of 76 firms from Australian stock market. To analyze this effect, two hypotheses are posited: the first one is that there is a positive relationship between environmental performance and financial performance in the time of economic growth and the second one is that there is no relationship between environmental performance and financial performance in the time of financial crisis. The results reveal that the positive relationship is statistically significant only in the time of economic growth.

In this study, the relationship between the environmental performance and the financial performance is investigated. The rest of paper is organized as follows. The second section discusses the aim of the study, defines the variables of the study. In the third part, the methodology is introduced and applied to find the relationship between the environmental performance and financial performance of Turkish firms. The fourth part is devoted to conclude the study.

\section{The Study}

\subsection{The Aim of the Study}

Recently, environmental factors are attracting the attention of both researchers and firms. People are more concerned about the environmental factors because of increasing pollution, decline in water resources and other reasons. Because of dirty water sources and air pollution, many people are dying day by day around the world. According to the global health observatory data $\% 23$ of all estimated global deaths are related with the unhealthy environmental factors such as air pollution and dirty water (WHO, 2016).

Some firms start to give importance to environmental issues and these firms' try to reduce gas emissions and to mitigate the climate change risk. The firms that take ISO 14000 certificate and/or issue environmental reports are increasing recent years. Decreasing gas emissions, clean technology, protecting environment are becoming more important in global business environment. Moreover being sensitive to environmental issues becomes a hallmark for global business environment.

Firms usually are double minded about investing in environmental issues because of the relationship between financial performances and investing in environmental issues. Some firms think that environmental efforts give competitive advantage by cost savings (using less energy, recycling of wastes etc.) and by attaining customer satisfaction, employee loyalty and by gaining positive image reputation and by complying with regulations (Lynes\&Drdge, 2006; Porter Van der Linde, 1995). On the other hand, if the firm invest in poor environmental efforts, the financial performance will be affected negatively because of inefficiency and useless investments (Reinhardt, Porter Van der Linde, 1995).

Due to the increased public concern both in Turkey and in the rest of the world, environmental issues are very important in attaining firm reputation. However, as it is mentioned above, there is a discord in the reality about the relationship between the environmental performance and the financial performance of the firms. For this reason, in this study it is aimed to analyze the relationship of financial performance and environmental performance of the firms operating in Turkey.

\subsection{Variables}

In the study, three variables are used. 2 of them are used for measuring financial performance, one of them is used for measuring environmental performance.

- Variables Used for Measuring Financial Performance

Mangolis etc. (2003) examine the empirical studies that investigate the relationship between firms' social and financial performance between 1972 and 2002 period. In general, accounting performance and market performance measures are used to analyze the financial performance of the firms. Accounting performance measures include 
return on asset, return on investment, profit margins and etc. While market performance includes market value to book value, stock performance and etc.

In the study, Return on Asset and Market Value/Book Value (MV/BV) ratios are used as a variables concerning financial performance. Return on Asset (ROA) is used for measuring the firm's accounting performance and Market Value/Book Value ratio is used to measure the market value. High MV/BV and high ROA values mean high financial performance.

In the study, it is analyzed that the effect of environmental performance on financial performance and it is compared which one is mostly affected by environmental performance; market performance or accounting performance. The financial ratio values are determined by using Finnet 2000 program.

- Variable Used for Measuring Environmental Performance

The environmental performance score of the firms are based on the data obtained by CDP Turkey Climate Change report. Each year firms from around the world are scored based on their environmental performance and disclosure in CDP environmental Climate Change report since 2010. CDP reports are formed by gathering information through questionnaires that are conducted on the firms.

Each year the number of the firms participated in CDP Turkey climate change program increases. In 2010 only 10 firms participated the CDP Turkey climate change program, while, in 2015, 38 firms participated the CDP Turkey climate program.

In the study, the financial scores are also needed so only publicly held firms are chosen as a sample. So only 30 firms are chosen as sample which have both financial scores and environmental performance for 2015 year. 8 of them are omitted from the study as they have no financial scores.

The firms that have a high performance score from CDP Climate Change report means that the firm is measuring and managing its carbon footprint. In other words, the firms that have high CDP climate performance scores give importance to carbon reduction, try to reduce emissions in their operations and save energy by changing machines or equipment or replace their energy resources from fuel resources to renewable energy resources. So high performance score in CDP Climate Change report means high environmental performance.

\section{Methodology}

\section{- Data}

This research investigates the correlation between Turkish firms' financial and environmental performance. For this reason a sample of firms was selected from CDP Climate Change Report. Total 38 firms participated the CDP Climate Change Report but the financial data is available for 30 of these firms. So the sample consists of 30 firms that have both financial and environmental scores.

\section{- Procedure and Results}

In the study, correlation analysis is used to analyze the relationship between the financial performance and environmental performance of the firms. Correlation analysis is performed by using Stata 14 program. Table 1 shows the sampled firms and their environmental performance scores, MV/BV ratio values and ROA scores for 2015 year. At the end of the table the correlation coefficient of environmental performance with financial parameters.

The analysis shows that the environmental performance have positive correlation with accounting measures (ROA) and market measures (BV/MV ratio). On the other words, ROA and MV/BV scores increase with higher environmental performance which is consistent with the expectations. Margolis and Walsh (2003) examine the empirical studies that investigates the association between firms' environmental efforts and financial performance for 30 years. According to their findings almost half of the studies ( 54 of 109 studies) find positive relation between firms' environmental efforts and financial performance, only 7 studies point to a negative relationship between environmental efforts and financial performance. The remaining studies reported non-significant relationships or mixed set of findings.

The relationship between MV/BV and environmental performance is weaker than the relationship with ROA and environmental performance as the correlation is at 0.1444 for $\mathrm{MV} / \mathrm{BV}$ and environmental performance whereas the correlation is at 0.2834 for ROA. As a result, environmental efforts affect highly accounting performance. The relationship between accounting performance and environmental performance is stronger than the relationship between marketing performance and environmental performance, it is probably because of increase in fuel efficiency, replacement of inefficient machines and equipments. These efforts both contribute to accounting performance and environmental performance.

The positive correlation between the environmental performance and market performance is weaker than the relationship between accounting performance and environmental performance that may be because investor has not given too much concern about environmental issues while purchasing stocks of firms in Turkey yet. 


\begin{tabular}{|c|c|c|c|c|}
\hline & Firm Name & $\begin{array}{l}\text { Environmental Performance Score } \\
\text { (EP Score) }\end{array}$ & MV/BV Ratio & ROA Score \\
\hline 1 & Afyon Çimento & 60 & 3.74 & 6.40 \\
\hline 2 & Akbank & 79 & 1.24 & 1.42 \\
\hline 3 & Akçansa & 92 & 2.31 & 17.00 \\
\hline 4 & Ak Enerji & 88 & 0.57 & -8.19 \\
\hline 5 & Alarko Holding & 17 & 0.42 & -5.62 \\
\hline 6 & Arçelik & 96 & 2.77 & 6.87 \\
\hline 7 & Aselsan & 95 & 3.55 & 3.76 \\
\hline 8 & Brisa & 98 & 3.93 & 10.38 \\
\hline 9 & Çelebi Hava Servis & 70 & 5.55 & 13.27 \\
\hline 10 & Çimsa Çimento & 93 & 1.84 & 14.06 \\
\hline 11 & Coca Cola & 94 & 2.84 & 1.45 \\
\hline 12 & Doğan Şirketler Grubu & 31 & 0.58 & -2.25 \\
\hline 13 & İhlas Holding & 30 & 0.41 & -3.06 \\
\hline 14 & Kardemir Karabük & 72 & 0.83 & -0.49 \\
\hline 15 & Migros A.Ş. & 82 & 6.78 & -6.53 \\
\hline 16 & Netaş Telek & 61 & 1.60 & 3.04 \\
\hline 17 & Zorlu Enerji & 92 & 0.22 & -5.06 \\
\hline 18 & Pegasus Hava & 93 & 1.15 & 2.97 \\
\hline 19 & Sabanc1 Holding & 94 & 0.98 & 0.90 \\
\hline 20 & Şekerbank & 89 & 0.73 & 0.45 \\
\hline 21 & Garanti & 98 & 1.14 & 1.45 \\
\hline 22 & T. Sınai Kalkınma Bankası & 99 & 1.17 & 2.33 \\
\hline 23 & T. Şise Ve Cam & 91 & 0.96 & 5.16 \\
\hline 24 & Tav Hav. & 89 & 2.33 & 7.04 \\
\hline 25 & Tofaş & 93 & 4.41 & 9.78 \\
\hline 26 & Turkcell & 97 & 1.78 & 9.94 \\
\hline 27 & Türk Halk Bankası & 93 & 0.70 & 1.35 \\
\hline 28 & Türk Vakıflar Bankası & 91 & 0.74 & 1.13 \\
\hline 29 & Vestel Beyaz Eşya & 62 & 3.14 & 13.27 \\
\hline \multirow[t]{2}{*}{30} & Vestel Elektronik & 95 & 1.54 & 0.72 \\
\hline & $\begin{array}{l}\text { Correlation Coefficient of Environmental } \\
\text { Performance with Financial Parameters }\end{array}$ & 1 & 0.1444 & 0.2834 \\
\hline
\end{tabular}

Table 1: The Relationship of Enviromental and Financial Performance of Turkish Firms

In order to map the relative positioning of the sampled firms in terms of their environmental performance and financial performance, multi dimensional scaling technique is utilized. ROA scores are preferred for measuring their financial performance because ROA and environmental performance have higher correlation compared to $\mathrm{MV} / \mathrm{BV}$ and environmental performance.

Multi dimensional scaling technique enables to show the dissimilarity or similarity of variables. In this study the firms are mapped to their similiratity and dissimilarity to their financial performance and environmental performance. With multidimensional scaling technique a map is produced which clusters the firms in terms of their distances among the environmental and financial performance of firms.

In multi dimensional scaling method similarity and dissimilarity of objects are formed with the help of Euclidean distances. Stata 14 program is used for multi dimensional scaling analysis. Figure 1 illustrates the map that shows the relative distance of the firms in terms of their financial performance and environmental performance.

The map consists of 4 parts. Part I consists of the firms that have both high financial performance and high environmental performance. In part I, 8 firms exist; these firms are Akçansa, Arçelik, Brisa, Çimsa Çimento, T.Şise ve Cam, Tav. Hav., Tofaş and Turkcell. In this section the firms are among the ones that have the highest financial score and the environmental score. This result is consistent with the result of correlation analysis performed. The firms clustered in part I are more concerned with environmental issues and have good financial performance.

Part II consists of the firms that have high environmental performance but low financial performance. The firms in part II are; Ak Enerji, Aselsan, Coca Cola, Zorlu Enerji, Pegasus Hava, Sabancı Holding, Sekerbank, Garanti T. Sınai Kalkınma Bankası, T. Şişe ve Cam, Tav. Hav., Tofaş, Turkcell, Türk Halk Bankası, Türk Vakıflar Bankası, Vestel Beyaz Eşya and Vestel Elektronik. This result is inconsistent with the correlation results. This cause weak the correlation coefficient. Several factors may cause to low financial performance of the firms. The low financial performance may be the result of deficiency of capital, bad management or inefficient internal operations. 
Part III consists of the firms that have both low financial performance and low environmental performance. Firms in part III are; Akbank, Alarko Holding, Doğan Şirketler Grubu, İhlas Holding, Kardemir Karabük and Migros A.Ş. In this section the firms perform poor in both financially and environmentally. This result is consistent with the result of the correlation analysis.

Part IV consists of the firms that have high financial score and low environmental performance. In this part the firms have the lowest environmental score among the sampled firms. Firms in part IV are; Afyon Çimento, Çelebi Hava Servs, Netaş Telek., and Vestel Beyaz Eşya.

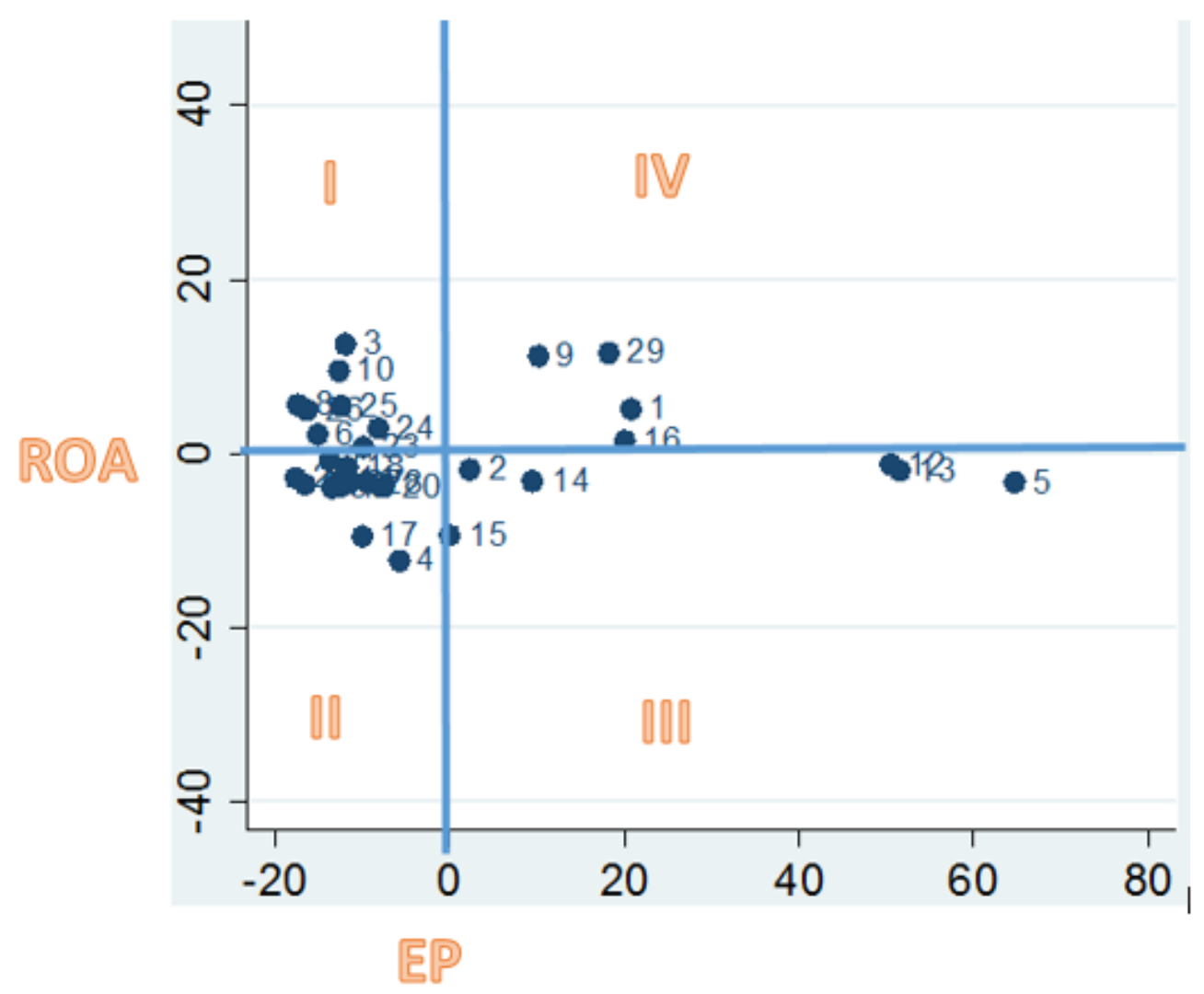

Figure 1. The Map: Environmental Performances (EP) and Return on Asset (ROA)

\section{Conclusion}

More and more environmental issues become important as a result of increase in air pollution, decrease in water resources and increase in other environmental problems. As a result businesses are forced to make arrangements about environmental issues legally or the firms are making arrangements about environmental issues with their own will. In both cases, the firms are anxious about the effect of investing in environmental issues on financial performance. Investing in environmental issues may affect the financial performance positively if the firm gain cost savings through environmental investments such as using less energy, replacement of old technology or increasing efficiencies. On the other hand, if the firm invest in poor environmental investments, this will affect the financial performance negatively.

In this study, it is aimed to analyze the relationship between environmental performance and financial performance of the firms operating in Turkey. The environmental performances of the firms are evaluated with the climate change scores. CDP Turkey Climate Change report calculates the firms' climate change score in the framework of the adaption to climate change, transparency and decrease in emissions. The financial performances of the firms are evaluated with return on asset and market value/book value measures. Market value/book value ratio is selected to analyze the market performance of the firms so that it can be possible to determine how much investors care about the environmental performance of the firms while purchasing the stocks. Return on asset ratio is selected to analyze the accounting performance of the firms.

The sample of the study consists of the firms that have both financial scores and have environmental scores. 30 firms are selected as a sample. The relationship between the environmental performance and financial performance of the firms are compared with the help of correlation analysis. Results of the correlation analysis reveal that there is a positive relation between environmental performance and financial performance. The relationship between 
market performance and environmental performance is weaker than the relationship with accounting and environmental performance. As a result it can be stated that environmental efforts affect the accounting performance more than the market performance. This may be the result of environmental efforts are increasing the productivity of the operations which affect the accounting performance of the firms positively. And also investors may not pay attention about environmental issues while purchasing stocks of firms in Turkey yet.

In the last part of the study the firms are clustered due to their environmental and financial performances with the help of multidimensional scaling technique. A map is developed that clusters the firms according to their similarity and dissimilarity to their financial performance and environmental performance.

A map consists of 4 parts. The firms clustered in Part I perform good in financial performance and environmental performance, the firms clustered in part II perform low in financial performance but good in environmental performance, the firms clustered in part III perform low in both financial performance and environmental performance, the firms clustered in part IV perform high in financial performance but low in environmental performance.

In future research it is needed to expand the observation period (maybe 5-10 years) and the sample. But the real problem is accessing to data in Turkey. The financial performance of the firms is only accessible if they are publicly held and the environmental data of the firms is very hard to access. If all the firms declare their environmental investments and financial scores, the sample and the observation period may be enriched.

\section{References}

- Bekmezci, M., 2014. "Strategies for Corporate Sustainability", Journal of Management, Marketing and Logistics - (JMML), 1(3), p. 218-240.

- Jiménez, J.B, Brust, D.V., Úbeda, J.P., Dijkshoorn, J., 2013. "Environmental protection and financial performance: an empirical analysis in Wales", International Journal of Operations \& Production Management, 33(8), p. 981 - 1018.http://dx.doi.org/10.1108/IJOPM-11-2010-0374.

- $\quad$ Lynes, J. K., \& Dredge, D., 2006. “Going green: motivations for environmental commitment in the airline industry: A case study of Scandinavian airlines”. Journal of Sustainable Tourism, 14, p.116-138. http://dx.doi.org/10.1080/09669580608669048

- Moneva, J., Ortas, E., 2010. "Corporate environmental and financial performance: a multivariateapproach", Industrial Management \& Data Systems, 110 (2), p.193-210. http://www.emeraldinsight.com/doi/ab S/10.1108/02635571011020304

- Margolis, J., Walsh, J., 2003. "Misery loves firms: Rethinking social initiatives by business", Administrative Science Quarterly, 48 (2), p. 268-305

- Muhammad, N., Scrimgeour, F., Reddy, K., Abidin, S., 2015. "The relationship between environmental performance and financial performance in periods of growth and contraction: evidence from Australian publicly listed firms", Journal of Cleaner Production, 102, p.324-332, http://dx.doi.org/10.1016/j.jclepro.2015.04.039

- $\quad$ Pointing, C., 2007, A New Green History of the World, The Environment and the Collapse of Great Civilizations, Penguen Books, United States of America

- $\quad$ Porter, C. Van der Linde, 1995. "Toward a new conception of the environment competitiveness relationship", Journal of Economic Perspectives, 9 (4) , p. 97-118

- Qi, G.Y., Zeng, S.X., Jonathan J. Shi, J.J., Meng, X.H., Lin, H., Yang, Q.X., 2014. "Revisiting the relationship between environmental and financial performance in Chinese industry". Journal of Environmental Management. 145, p.349-356. http://dx.doi.org/10.1016/j.jenvman.2014.07.010

- Reinhardt F.(1998), “Environmental product differentiation: Implications for corporate strategy”, California Management Review, 40 (4) , p. 43-73

- Sahay, A., Singh, N.P., 2005. "Indian corporate environmental and financial performance: empirical relationship between them", Journal of Advances in Management Research, 2 (1), p. 79 - 88. http://dx.doi.org/10.1108/97279810580000373

- Sukhdev, P., 2012. Corporation 2020: Transformin Business for Tomorrow's World, Island Press, Washington D.C

- World Health Organization(WHO), 2016. http://www.who.int/gho/en/ 